\title{
МАТЕМАТИЧНА МОДЕЛЬ ПРОГНОЗУВАННЯ ВИНИКНЕННЯ ПРЕЕКЛАМПСІЇ СЕРЕДНЬОГО СТУПЕНЯ У ЖІНОК ГРУПИ ВИСОКОГО РИЗИКУ РОЗВИТКУ ПІЗНЬОГО ГЕСТОЗУ НА ТЛІ МЕТАБОЛІЧНОГО СИНДРОМУ
}

\author{
○С. В. Хміль, У. Я. Франчук, Л. М. Маланчук, М. В. Франчук \\ Тернопільський національний медичний університет імені І. Я. Горбачевського МОз України
}

\begin{abstract}
РЕзЮМЕ. В Україні наявна тенденція до збільшення розвитку ускладнення вагітності пізніми гестозами, тому дослідження методом математичного моделювання прогнозування виникнення прееклампсії середнього ступеня $є$ доцільним та необхідним для спрощення верифікації даної патології.

Мета - розроблення математичної моделі для визначення ймовірності та відсотка прогнозування виникнення прееклампсії середнього ступеня у жінок групи високого ризику розвитку пізнього гестозу на тлі метаболічного синдрому.

Матеріал і методи. На сьогодні, окрім точної діагностики та ефективного лікування прееклампсії з ожирінням, постало питання прогнозування виникнення прееклампсії за допомогою біохімічних маркерів діагностики. Іншими словами, з якою ймовірністю може виникнути прееклампсія середнього ступеня у жінок групи ризику виникнення пізнього гестозу на тлі метаболічного синдрому. Для вирішення завдань такої складності застосували нейронні мережі, або «штучний інтелект».

Результати. Математично доведено, що при наявності протеїнурії, що відповідає діагностичним критеріям прееклампсії легкого ступеня, дефіциту вітаміну D та підвищення рівня інгібіну A, ймовірність розвитку прееклампсії середнього ступеня становить $89 \%$.

Висновки. У пацієнток віком понад 35 років ризик виникнення прееклампсії середнього ступеня, враховуючи додаткові прогностичні маркери, зокрема вітамін D та інгібін A, зростає ймовірність розвитку даного ускладнення вагітності на тлі метаболічного синдрому.

КлючовІ СлОВА: пізній гестоз; вітамін D; інгібін A; нейронні мережі.
\end{abstract}

Вступ. Пізній гестоз є одним із важливих ускладнень вагітності. Незважаючи на досягнення сучасної медицини, у світовій структурі материнської смертності впродовж останніх десяти років прееклампсія стабільно посідає 3-тє місце, після кровотеч і сепсису $[3,7,16]$. Сторіччя вивчення патогенезу цього стану сформували поетичні його назви - «великого маскувальника» або «хвороби виключення" через розмаїття, комплексність та підступність проявів $[8,12]$. Доведено, що при ранньому початку гестозу частота різних ускладнень в 1,5-3,4 раза вища, ніж при пізньому його прояві [15]. За останні роки проведено багато досліджень з приводу факторів ризику, патогенезу, лікування та профілактики гіпертензивних розладів і прееклампсії у вагітних $[2,11]$. Близько 30 \% населення планети страждають надлишковою масою тіла. Частота ожиріння серед жіночого населення, згідно з останніми даними, становить від 29,7 \% до 35,5\%. Число вагітних із ожирінням в економічно розвинених країнах сягає 35-38 \%, що збільшує частоту розвитку акушерських і перинатальних ускладнень приблизно на $50 \%$. Ожиріння $\epsilon$ головною ознакою, що входить до групи ризику виникнення МС [14]. Поширеність МС у жінок репродуктивного віку становить від $6 \%$ до $35 \%$. Серед жінок із ожирінням розповсюдженість МС складає 50-60 \%, а серед вагітних коливається від 14 до 24 \% [13]. До теперішнього часу не систематизовані відомості про значні порушення в становленні репродуктивної системи, при вагітності, гінекологічних захворюваннях у жінок із МС [17]. Прееклампсія $\epsilon$ синдромом, специфічним для вагітності. Однією з гіпотез щодо етіології прееклампсії $\epsilon$ дефіцит вітаміну D під час вагітності [1]. Дефіцит вітамінів, мікронутрієнтів, гормонів лежить в основі різноманітної патології людини. На сьогодні надзвичайно актуальною $\epsilon$ проблема дефіциту вітаміну $\mathrm{D}$, оскільки, як свідчать результати чиселенних досліджень, його нестача виявляється у половини населення світу. Згідно з сучасними уявленнями, дефіцит вітаміну D пов'язаний з підвищеним ризиком розвитку цукрового діабету, артеріальної гіпертензії, серцево-судинної патології, злоякісних новоутворень, автоімунних і запальних захворювань, підвищеним рівнем смертності. Припускають, що нестача або дефіцит вітаміну D патогенетично пов'язані з розвитком прееклампсії, гестаційного діабету, низької маси при народженні, передчасними пологами, інфекційними ускладненнями тощо $[4,18]$, це зумовлює зростання інтересу до кількісної оцінки вмісту вітаміну D та розуміння механізмів взаємозв'язку нестачі вітаміну D з ускладненнями вагітності $[5,6,18]$.

Рівень інгібіну А в сироватці крові може бути корисним біомаркером для діагностики та моніторингу ПЕ. Інгібін А та інші маркери сироватки другого триместру можуть бути корисними для раннього виявлення прееклампсії $[9,10]$. Важли- 
Огляди літератури, оригінальні дослідження, погляд на проблему, випадок з практики, короткі повідомлення вим для діагностики та прогнозування прееклампсії $\epsilon$ визначення ймовірності виникнення даного ускладнення.

Мета - розроблення математичної моделі для визначення ймовірності та відсотка прогнозування виникнення прееклампсії середнього ступеня у жінок групи високого ризику розвитку пізнього гестозу на тлі метаболічного синдрому.

Матеріал і методи дослідження. На сьогодні, окрім точної діагностики та ефективного лікування прееклампсії з ожирінням, постало питання прогнозування виникнення прееклампсії за допомогою біохімічних маркерів діагностики. Іншими словами, з якою ймовірністю може виникнути прееклампсія середнього ступеня у жінок групи ризику виникнення пізнього гестозу на тлі метаболічного синдрому. Для вирішення завдань такої складності застосували нейронні мережі, або «штучний інтелект». Нейронні мережі $\epsilon$ нелінійними системами, що дозволяють класифікувати дані набагато краще, ніж звичайні лінійні методи. Активне застосування вони отримали і в медицині. Можливість значно підвищити специфічність діагностики, не знижуючи її чутливості, - ось основна мета нейронних мереж.

Результати й обговорення. Для побудови математичної моделі прогнозування виникнення прееклампсії середнього ступеня за допомогою нейронної мережі у жінок групи високого ризику розвитку пізнього гестозу на тлі метаболічного синдрому, в якості вхідної інформації потрібно обрати показники, котрі найбільше корелюють 3 виникненням прееклампсії у даної когорти жінок. Можна виділити декілька чинників, що найбільше пов'язані з розвитком прееклампсії середнього ступеня. До них належать вік жінок більше 35 років, наявність протеїнурії, визначення сечовини в крові, сечової кислоти в крові, АЛТ і АСТ у біохімічному аналізі крові, рівень вітаміну D та визначення інгібіну $A$, що відповідає вектору I.

$I^{\text {MIN }}=(0 ; 0 ; 1.6 ; 0.15 ; 0 ; 0 ; 11 ; 0)$ - мінімально можливі покажчики з вищезазначених вимірювань.

$I^{\text {мAX }}=(1.0 ; 3.5 ; 8.3 ; 0.45 ; 65 ; 57 ; 50 ; 456)$ - максимально можливі покажчики з вищезазначених вимірювань.

Тоді ймовірність наявності прееклампсії середнього ступеня у жінок групи високого ризику розвитку даного ускладнення вагітності, визначається за формулою:

$$
P(\mathrm{I})=\frac{1}{1+e^{-5 D * W}},
$$

де $W=(0.48 ; 8.63 ; 5.45 ;-1.62 ;-1.54 ;-0.17 ;-1.68 ;-1.21)^{T}$

$$
D=\left(d_{1}, d_{2}, \ldots, d_{8}\right), \quad d_{j}=\frac{I_{j}-I_{j}^{M I N}}{I_{j}^{M A X}-I_{j}^{M I N}} j=\underline{1,8},
$$

де $P(I)$ - probability (Ill), ймовірність наявності прееклампсії середнього ступеня; $W$ - weight, вектор

ваг синаптичних дуг штучного нейрона; $D$ - data, дані хворого, відмасштабовані на інтервал 0-1, таким чином, що мінімально можливому значенню відповідав 0, а максимально можливому - 1; е число Ейлера.

Приклад обчислення.

Формування вхідного вектора І. Позначимо вектором / показники хворого з таких вимірювань: вік жінок більше 35 років, наявність протеїнурії, визначення сечовини в крові, сечової кислоти в крові, АЛТ і АСТ в біохімічному аналізі крові, рівень вітаміну D та визначення інгібіну $A(I=1 ; 1.45 ; 3.5$; $0.45 ; 40 ; 48 ; 18 ; 420)$.

Обчислення вектора $D$. Тепер нам необхідно «відмасштабувати» ці дані на відрізок 0 - 1, тобто, щоб мінімально можливим значенням був 0, а максимально можливим - 1. Для цього нам знадобляться вектори / ${ }^{\text {MIN }}$ та / ${ }^{\text {MAX }}$ :

$I^{\text {MIN }}=(0 ; 0 ; 1,6 ; 0,15 ; 0 ; 0 ; 11 ; 0)$ - мінімально можливі показники з вищезазначених вимірювань;

$I^{\text {MAX }}=(1 ; 3,5 ; 8,3 ; 0,45 ; 65 ; 57 ; 50 ; 456)$ - максимально можливі показники з вищезазначених вимірювань.

Вектор $D=\left(d_{1}, d_{2}, \ldots d_{8}\right)$ обчислюється за наступною формулою:

$$
d_{j}=\frac{I_{j}-I_{j}^{M I N}}{I_{j}^{M A X}-I_{j}^{M I N}} j
$$

Обчислення добутку векторів $D$ та $W$.

Маємо вектор $W$ з константними значеннями: $W=(0.48 ; 8.63 ; 5.45 ;-1.62 ;-1.54 ;-0.17 ;-1.68 ;-1.21)$.

Тепер можемо обчислити їх матричний добуTOK:

Отже, $D \times W=2.29$

Фінальне обчислення ймовірності наявності даного ускладнення вагітності:

Отримуємо фінальну відповідь:

$P(\mathrm{I})=\frac{1}{1+e^{-5 D * W}}=1,00$ а6о $100 \%$

Отже, вірогідність виникнення прееклампсії середнього ступеня у даної пацієнтки становить 100 \%. Для полегшення математичних обчислень створено своєрідний «калькулятор» прогнозування ризику виникнення прееклампсії середнього ступеня у жінок групи високого ризику розвитку пізнього гестозу на тлі метаболічного синдрому. Цю формулу внесено в програму для роботи з електронними таблицями Microsoft Office Excel, де достатньо лише заповнити вхідні дані пацієнта (вік жінок більше 35 років, наявність протеїнурії, визначення сечовини в крові, сечової кислоти в крові, АлТ і АСТ в біохімічному аналізі крові, рівень вітаміну D та визначення інгібіну A) у відповідних комірках і автоматично отримати ймовірність розвитку пізнього гестозу (рис. 1).

При наявності таких критеріїв як вік пацієнтки понад 35 років, протеїнурія понад 0,3 ммоль/л, 
Огляди літератури, оригінальні дослідження, погляд на проблему, випадок з практики, короткі повідомлення рівень сечовини в крові понад 4,5 ммоль/л, рівень сечової кислоти понад 0,45 ммоль/л, підвищення рівнів АЛТ та АCT, дефіцит вітаміну D

та підвищення інгібіну А - ймовірність розвитку прееклампсії середнього ступеня складає $100 \%$.

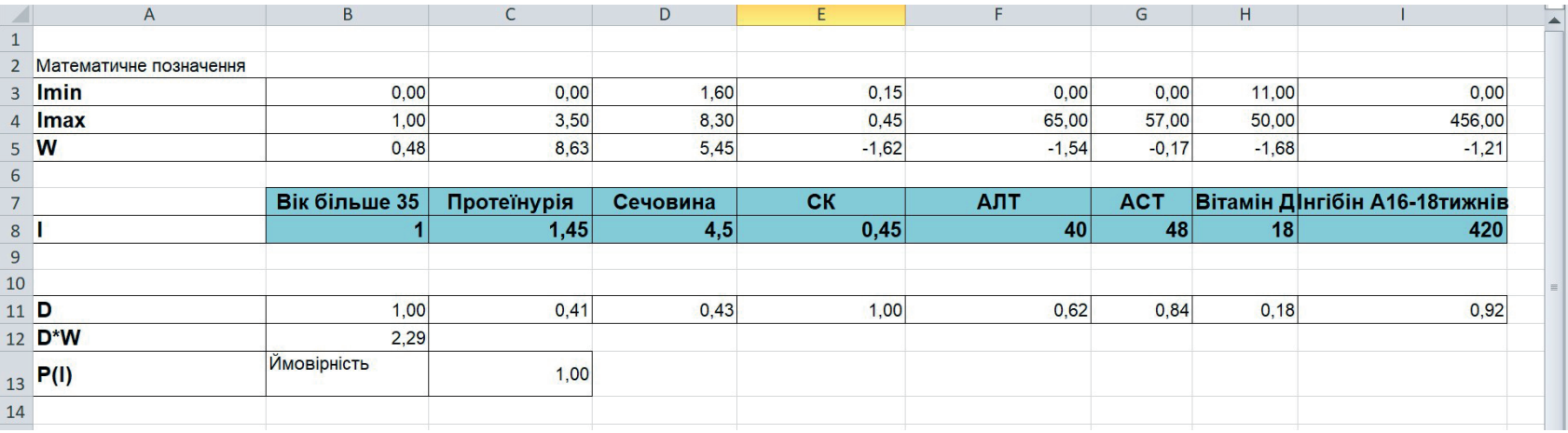

Рис. 1. Приклад 1. Калькулятор прогнозування прееклампсії середнього ступеня (ймовірність розвитку $100 \%)$.

Висновки. Досліджено, що при наявності протеїнурії, що відповідає діагностичним критеріям прееклампсії легкого ступеня, дефіциту вітаміну D та підвищення рівня інгібіну $A$, ймовірність розвитку прееклампсії середнього ступеня стано-

вить 89 \% (рис. 2). Враховуючи дані, наведені у таблиці, можна зробити висновок, що у пацієнток віком понад 35 років зростає ймовірність розвитку даного ускладнення вагітності на тлі метаболічного синдрому.

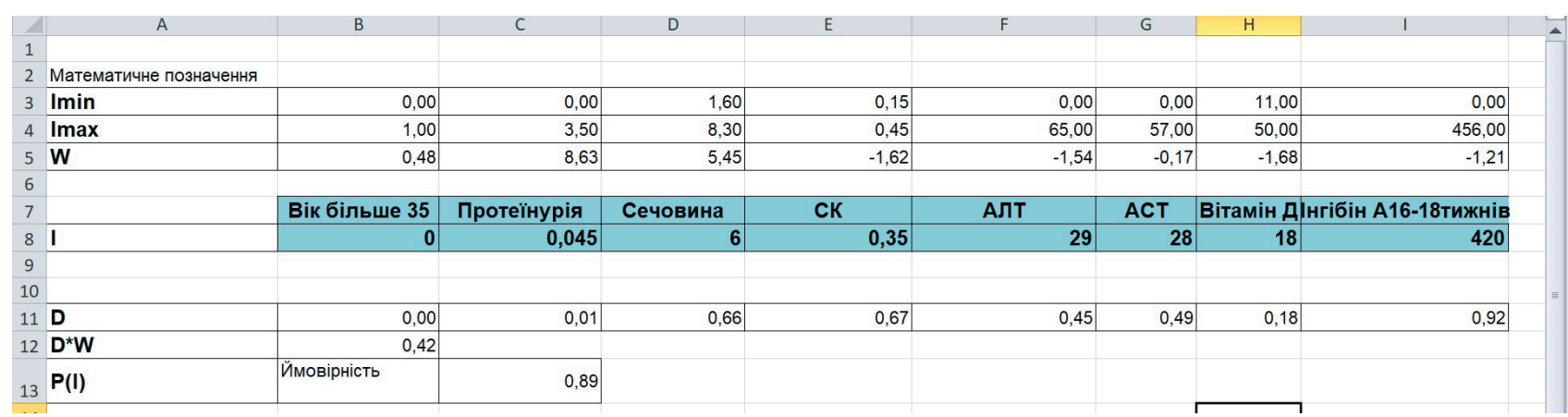

Рис. 2. Приклад 2. Калькулятор прогнозування прееклампсії середнього ступеня (ймовірність розвитку 89 \%).

Перспективи подальших досліджень. Метою наших подальших досліджень $є$ вчасна профілактика виникнення пізнього гестозу, застосовуючи додаткові маркери діагностики, зокре- ма визначення рівнів вітаміну D та інгібіну A, у жінок групи високого ризику розвитку пізнього гестозу на тлі метаболічного синдрому.

\section{ЛІТЕРАТУРА}

1. The effects of vitamin $d$ supplement on prevention of recurrence of preeclampsia in pregnant women with a history of preeclampsia / S. Behjat Sasan, F. Zandvakili, N. Soufizadeh, E. Baybordi // Obstet. Gynecol. Int. 2017. - Vol. 2017. - 8249264. DOI: 10.1155/2017/8249264.

2. Diagnosis, evaluation, and management of the hypertensive disorders of pregnancy: executive summary / L. A. Magee, A. Pels, M. Helewa [et al.] // J. Obstet. Gynaecol. Can. - 2014. - Vol. 36 (5). - P. 416-438.

3. Global cause sof maternal death: a WHO systematic analysis / L. Say, D. Chou, A. Gemmill [et al.] // Lancet Glob. Health. - 2014. - Vol. 2 (6). - P. 323-333.
4. Vitamin D receptor (VDR) polymorphisms are associated to spontaneous preterm birth and maternal aspects / N. Javorski, C. A. D. Lima, L. V. C. Silva [et al.] // Gene. - 2017. -pii: S0378-1119(17)30933-2. DOI: 10.1016/j. gene.2017.10.087.

5. Karras S. N. Understanding vitamin D metabolism in pregnancy: From physiology to pathophysiology and clinical outcomes / S. N. Karras, C. L. Wagner, V. D. Castracane // Metabolism. - 2017. - pii: S0026-0495(17)30275-5. DOI: 10.1016/j.metabol.2017.10.001.

6. Maternal Vitamin D status and the relationship with neonatal anthropometric and childhood neurodeve- 
Огляди літератури, оригінальні дослідження, погляд на проблему, випадок з практики, короткі повідомлення lopmental outcomes: results from the seychelles child development nutrition study / E. Laird, S. W. Thurston, E. van Wijngaarden [et al.] // Nutrients. - 2017. - Vol. 9 (11). - pii: E1235. DOI: $10.3390 /$ nu9111235.

7. Pre-eclampsia / E. A. Steegers, P. von Dadelszen, J. J. Duvekot, R. Pijnenborg // Lancet. - 2010. - Vol. 376 (9741). - P. 631-644.

8. Redman C. Pre-eclampsia: A complex and variable disease / C. Redman // Pregnancy Hypertens. - 2014. Vol. 4 (3). - P. 241-242.

9. Early detection of preeclampsia using inhibin a and other second-trimester serum markers / P. H. Ree, W. B. Hahn, S. W. Chang [et al.] // Fetal. Diagn. Ther. 2011. - Vol. 29 (4). - P. 280-286. DOI: 10.1159/000322742.

10. Placental and maternal serum inhibin $A$ in patients with preeclampsia and small-for-gestational-age / Z. Shen, L. Y. Cai, I. S. Suprapto [et al.] // J. Obstet. Gynaecol. Res. - 2011. - Vol. 37 (10). - P. 1290-1296. DOI: $10.1111 / \mathrm{j} .1447-0756.2010 .01513 . x$.

11. SOMANZ guidelines for the management of hypertensive disorders of pregnancy 2014 / S. A. Lowe, L. Bowyer, K. Lust [et al.] // Aust. N Z J. Obstet. Gynaecol. 2015. - Vol. 55 (5). - P. 1-29.

12. Венцківська І. Б. Нові підходи до оцінки стану плацентарного кровообігу при тяжких формах прееклампсії / І. Б. Венцківська, Я. М. Вітовський, О. С. Загородня // 36. наук. праць асоціації акушер-гінекологів України. - 2017. - № 2 (40). - С. 40-44.

\section{REFERENCES}

1. Behjat Sasan, S., Zandvakili, F., Soufizadeh, N., \& Baybordi, E. (2017). The effects of vitamin d supplement on prevention of recurrence of preeclampsia in pregnant women with a history of preeclampsia. Obstet. Gynecol. Int., 8249264. DOI: 10.1155/2017/8249264.

2. Magee, L.A., Pels, A., Helewa, M., Rey, E., \& von Dadelszen, P. (2014). Diagnosis, evaluation, and management of the hypertensive disorders of pregnancy: executive summary. J. Obstet. Gynaecol. Can., 36 (5), 416-438.

3. Say, L., Chou, D., Gemmill, A., Tunçalp, Ö., Moller, A.B., Daniels, J., ..., \& Alkema, L. (2014). Global cause sof maternal death: a WHO systematic analysis. Lancet Glob Health, 2 (6), 323-333.

4. Javorski, N., Lima, C.A.D., Silva, L.V.C., Crovella, S., \& de Azêvedo Silva, J. (2017). Vitamin D receptor (VDR) polymorphisms are associated to spontaneous preterm birth and maternal aspects. Gene, pii: S03781119(17)30933-2. DOI: 10.1016/j.gene.2017.10.087.

5. Karras, S.N., Wagner, C.L., \& Castracane, V.D. (2017). Understanding vitamin D metabolism in pregnancy: From physiology to pathophysiology and clinical outcomes. Metabolism, pii: S0026-0495(17)30275-5. DOI: 10.1016/j.metabol.2017.10.001.

6. Laird, E., Thurston, S.W., van Wijngaarden, E., Shamlaye, C.F., Myers, G.J., Davidson, P.W., ..., \& Strain, J.J. (2017). Maternal Vitamin D status and the relationship with neonatal anthropometric and childhood neurodevelopmental outcomes: results from the seychelles child development

nutrition study. Nutrients, 9 (11), pii: E1235. DOI: 10.3390/ nu9111235.

7. Steegers, E.A., von Dadelszen, P., Duvekot, J.J., \& Pijnenborg, R. (2010). Pre-eclampsia. Lancet, 376 (9741), 631-644.

8. Redman, C. (2014). Pre-eclampsia: A complex and variable disease. Pregnancy Hypertens, 4 (3), 241-242.

9. Ree, P.H., Hahn, W.B., Chang, S.W., Jung, S.H., Kang, J.H., Cha, D.H., ..., \& Huh, J.Y. (2011). Early detection of preeclampsia using inhibin a and other second-trimester serum markers. Fetal. Diagn. Ther., 29 (4), 280-286. DOI: $10.1159 / 000322742$.

10. Shen, Z., Cai, L.Y., Suprapto, I.S., Shenoy, P., \& Zhou, X. (2011). Placental and maternal serum inhibin $A$ in patients with preeclampsia and small-for-gestational-age. J. Obstet. Gynaecol. Res., 37 (10), 1290-1296. DOI: 10.1111/j.1447-0756.2010.01513.x.

11. Lowe, S.A., Bowyer, L., Lust, K., McMahon, L.P., Morton, M.R., North, R.A., ..., \& Said, J.M. (2015). SOMANZ guidelines for the management of hypertensive disorders of pregnancy 2014. Aust. N Z J. Obstet. Gynaecol., 55 (5), 1-29.

12. Ventskivska, I.B., Vitovskyi, Ya.M., \& Zahorodnia, O.S. (2017). Novi pidkhody do otsinky stanu platsentarnoho krovoobihu pry tyazhkykh formakh preeklampsii [New approaches to the assessment of placental circulation in severe forms of preeclampsia]. Zbirnyk naukovykh prats asotsiatsiii akusher-hinekolohiv Ukrainy-Collection of 
Огляди літератури, оригінальні дослідження, погляд на проблему, випадок з практики, короткі повідомлення Sci. Works of the Association of Obstetricians and Gynecologists of Ukraine, 2 (40), 40-44 [in Ukrainian].

13. Dyndar, O.A. (2016). Retrospektyvnyi analiz perebihu vahitnosti ta polohiv u zhinok iz metabolichnym syndromom [Retrospective analysis of pregnancy and childbirth in women with metabolic syndrome]. Zbirnyk naukovykh prats asotsiatsiii akusher-hinekolohiv Ukrainy - Collection of Sci. Works of the Association of Obstetricians and Gynecologists of Ukraine, 1 (37), 56-61 [in Ukrainian].

14. Ivanyuta, S.O., Dyndar, O.A., Makarenko, H.I., \& Kurochka, V.V. (2017). Metabolichnyy syndrom - pandemiya KHKHI stolittya, nahalna problema akusherstva. Zbirnyk naukovykh prats asotsiatsiii akusher-hinekolohiv Ukrainy Collection of Sci. Works of the Association of Obstetricians and Gynecologists of Ukraine, 2 (40), 134-138 [in Ukrainian].

15. Savelyeva, G.M., Krasnopolskiy, V.I., Strizhakov, A.N., Radzinskiy, V.Y., Shalina, R.I., \& Kurtser, M.A. (2013). Kakoy klassifikatsii gestozov (preeklampsii) dolzhen priderzhivatsya vrach v povsednevnoy rabote? [To what classification of gestosis (preeclampsia) should adhere a doctor in daily work?]. Zhurnal akusherstva i zhenskikh bolezney - Journal of Obstetrics and Women's Diseases, LXII, 1, 5-9. DOI: https://doi.org/10.17816/JOWD6215-9 [in Russian].

16. Kaminskyi, V.V., \& Zhuk, C.I. (2015). Shliakhy znyzhennia materynskoi smertnosti: ukrainski realii i mizhnarodnyi dosvid [Ways to reduce maternal mortality: Ukrainian realities and international experience]. Zhinochyi likar - Female Doctor, 2, 10-14 [in Ukrainian].

17. Ostafiichuk, S.O. (2017). Doklinichni markery rozvytku preeklampsii u zhinok z patolohichnym zbilshenniam masy tila pid chas vahitnosti [Preclinical markers of preeclampsia in women with pathological weight gain during pregnancy]. Zbirnyk naukovykh prats asotsiatsiii akusherhinekolohiv Ukrainy - Collection of Sci. Works of the Association of Obstetricians and Gynecologists of Ukraine, 2 (40), 203-207 [in Ukrainian].

18. Pyrohova, V.I., \& Zhemela, N.I. (2015). Do pytannia roli vitaminu $\mathrm{D}$ u zabezpechenni hestatsiinoho protsesu [On the role of vitamin $\mathrm{D}$ in ensuring the gestational process]. Zbirnyk naukovykh prats asotsiatsiii akusher-hinekolohiv Ukrainy - Collection of Sci. Works of the Association of Obstetricians and Gynecologists of Ukraine, 2 (36), 189-192 [in Ukrainian].

\title{
MATHEMATICAL MODEL FOR PREDICTING THE OCCURRENCE OF MODERATE PREECLAMPSIA IN WOMEN AT HIGH RISK OF DEVELOPING LATE GESTOSIS AGAINST THE BACKGROUND OF METABOLIC SYNDROME
}

\author{
๑S. V. Khmil, U. Ya. Franchuk, L. M. Malanchuk, M. V. Franchuk \\ I. Horbachevsky Ternopil National Medical University
}

SUMMARY. In Ukraine, there is a tendency to an increase in the development of complications of pregnancy with late gestosis, therefore, a study using the method of mathematical modeling to predict the occurrence of moderate preeclampsia is advisable and necessary to simplify the verification of this pathology.

The aim - development of a mathematical model to determine the probability and percentage of predicting the occurrence of moderate preeclampsia in women at high risk of developing late gestosis against the background of metabolic syndrome.

Material and Methods. To date, in addition to accurate diagnosis and effective treatment of preeclampsia with obesity, the question has arisen of predicting the development of preeclampsia, using biochemical diagnostic markers. That is, with what probability may moderate preeclampsia occur in women at risk of developing late gestosis against the background of metabolic syndrome. To solve problems of such complexity, neural networks or "artificial intelligence" were used.

Results. It has been mathematically proven that in the presence of proteinuria, which meets the diagnostic criteria for mild preeclampsia, vitamin D deficiency and an increase in inhibin A, the probability of moderate preeclampsia is $89 \%$.

Conclusions. In patients over 35 years of age, the risk of moderate preeclampsia, given additional prognostic markers, in particular vitamin D and inhibin A, increases the likelihood of developing this complication of pregnancy against the background of metabolic syndrome.

KEY WORDS: late gestosis; vitamin D; inhibin A; neural networks. 